\section{CHINESE CERAMIC GLAZES} WITH SPECIAL REFERENCE TO THOSE DERIVED FROM COPPER*

By A. L. HETHERINGTON, C.B.E. Honorary Secretary of the Oriental Ceramic Society

$\mathrm{T}$ HE Chinese potters exployed for the colouring of their glazes prior/to the fourteenth century two metals, an \& 8 ro on y, for the great majority of their effects. jyose ty 6 metals were iron and copper, and both ontinued/to be used extensively in sub. sequent bus. But other metals then came into widerfise as wey, notably cobalt for the well-known blue/and whit wares, and, later still, gold for the familiar groy known as famille rose.

The Chingse potter first used copper on an extensive scale for colouring his glazes in the T'ang dynasty, A.D. 618-906. In that dynasty the potter produced a variety of green glazes from cupric oxide which are relatively easy to produce. In the subsequent periods, green glazes were made in profusion and in a variety of shades. While there is not much evidence of copper greens in the succeeding Sung dynasty-960-1279, or, say, from the date of the crowning of Otto I as Holy Roman Emperor to that of the signing of Magna Carta-they were made in great variety in the Miing and Manchu dynasties; that is, during 1368-1912, or from the date of Chaucer to modern times.

Cupric oxide in a glaze gives rise to a range of colour from blue to green, and these colours are accounted for by the varying amounts of cupric oxide present and especially by the nature of the glazes in which it is incorporated. The more basic the glaze, the greater will be the tendency to a blue colour ; and the more acid the glaze, the greater will be the predominance of the green.

Cupric oxide dissolves in a glaze formed of potas. sium silicate or of sodium silicate, or a mixture of the two, to give a blue colour at about $1,300^{\circ} \mathrm{C}$. If alumina is present as well, there is a considerable tendency for the blue to turn to green. If lead is prescnt, the potash lead silicate glaze is blue, but tends to green if the lead is in excess. To retain a blue colour, the alkaline constituent must be relatively high, and if alkali is lost by volatilization, the glaze becomes acidic and green will result. But the alkali content must not be too high, since then the glaze becomes unstable and is liable to break down on exposure to a humid atmosphere.

The blue glazes from cupric oxide were not mastered until the Niing and Manchu dynasties. It was, and is, a difficult colour effect to produce. The greens from copper are relatively simple in comparison.

The fact that ceramic production in China from the Ming dynasty onwards was mainly centred in the ceramic metropolis of Ching-tê-chên, where an enormous number of operatives were employed under imperial patronage, no doubt accounts for the greater technical skill responsible for this and other glaze effects.

Under reducing conditions, copper in a glaze produces the range of reds which are familiar; the famous sang de touf and the peach-bloom glazes, as well as a variety of other shades of red, are due to copper. These copper-red glazes are brought about by the reduction of cupric oxide to the metal itself

* Summary of a Wednesday Evening Discourse at the Royal Institution, delivered on May 18. in a finely divided colloidal condition. In order to produce a clear blood-red glaze, not more than one half of one per cent of copper must be present. If more than that is put into the glaze, the colour becomes opaque, with a red sealing-wax appearance.

The chemistry of the copper-red glazes was estab. lished by Dr. J. W. Mellor and may be briefly summarized as follows. The red colour is due to the even aggregation of finely divided colloidal particles of copper to form a band in a certain portion of the glaze. The formation and maintenance of this red band are assisted by the presence of iron (or tin) oxide. The effect is brought about by a reducing atmosphere at the outset, and the glaze is finished otf in an oxidizing atmosphere.

Colloidal copper, when in a very fine state of division, is yellow; in a slightly less fine state it is red, and when the particles are slightly larger still, they look blue by transmitted light.

At the outset, under strong reducing conditions, the cupric oxide is reduced, and any iron present is reduced to ferrous oxide. The atmospheric oxygen, on its introduction, attacks the molten glaze and oxidizes the topmost layer, converting the copper to cupric oxide. As a result, the surface layer of a copper-red glaze is colourless, or faintly green from the small amount of copper in the glaze. Below that layer the oxidizing action is relatively slight, and a layer of yellow can generally be seen consisting of finely divided particles of colloidal copper. Below that layer there is no oxidizing action on the part of the atmospheric oxygen, and a red band of slightly larger sized colloidal particles appears, below which is a narrower band of blue particles of slightly larger size still. The iron oxide present helps to stabilize the colloidal copper and keep it dispersed to form and maintain the red band.

The famous peach-bloom glaze is a variety of the sang de boeuf in which the attack of the atmospheric oxygen is allowed to continue longer. As a result, the red colour is diminished to a pinkish-red with the blue particles showing faintly below it. Sometimes in these peach-bloom glazes, which are difficult to produce in perfection, green spots appear. These green spots are due to colloidal particles of copper forming small aggregations by flocculation. These are oxidized to cupric oxide by the atmospheric oxygen and immediately dissolve in the glaze to give the characteristic green of cupric oxide.

An on-glaze copper-red glaze which is entirely different from the in-glaze effect can be produced by the formation of a copper aerosol as a thin layer of copper particles near the surface of the glaze.

\section{OBITUARIES}

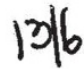

\section{Mr. F. N. Ashcroft}

Ir was with deep regets that his many friends heard of the sudden $9, \mathrm{~h}$ in London on April 4 of Frederick Noel Ashcr it. He Mad just completed a great task as pop rary teasurer to the Eighteenth Session of the Mternationdl Geological Congress. His careful at hition to detail and his devotion to the mpk contributed largely to the great success of the CCigress. He was publicly thanked for his work at a meeting of the Geological Society on March 23. Ashcroft brought to this task a wide knowledge of business accounts. He had been honorary treasurer of the Geological Society of London during 1929-47, 
and of the Mineralogical Society during 1920-42; also he was a managing trustee of the Geologists Association and of the Mineralogical Society. $\mathrm{He}$ was also honorary treasurer and vice-chairman of the Metropolitan District Nursing Association, with which he had been connected as a member of the Executive Committee since 1920. He was president of the Mineralogical Society during 1942-45, and at the time of his death he was its foreign secretary ; he was also a vice-president of the Geological Society.

To his many friends in London, it must have seemed that Ashcroft's whole life was devoted to the financial affairs of these societies; but he was first and foremost a mineralogist, and his lasting memorial in the years to come will be the two superb collections of minerals which he had presented, or has now bequeathed, to the British Museum (Natural History), documented with an accuracy which few others would have had the patience and knowledge to achieve.

Ashcroft went from Rugby to Miagdalen College, Oxford, in 1897, and gained a first in honours chemistry in 1901. He worked at Tübingen in 1901 and later at University College, London, in the Department of Organic Chemistry, and published a paper in the Journal of the Chemical Society in 1907. At Oxford he had also studied mineralogy under Miiers, from whom, like so many others, he acquired an interest in minerals which decided the main lines of his future work. Illhealth prevented him from undertaking any full-time work; but Ashcroft could not be idle and he devoted himself to the study and collection of minerals, working partly in the Mineral Department of the British viuseum and partly in the Chemistry Department of University College, London, where J. Norman Collie, himself a fair mineralogist, was professor. At first specializing in zeolites, Ashcroft brought together in the course of ten years or so a notable collection of these minerals from all over the world. In 1914 he presented the bulk of this collection to the British Miuseum, retaining only his Irish specimens, intending to continue publishing accounts of these when time allowed. It was well after the conclusion of peace, in 1920, that Asheroft turned his attention to the minerals of the Swiss Alps. Here he set out not merely to acquire fine specimens, but also to record the exact localities where each was found and to collect representative specimens of all the minerals associated in each locality, thus bringing together all the data for a complete study of the distribution and paragenesis of the minerals. Carrying a heavy camera, hammers and chisels, he went round the recently worked localities with the mineral collectors on his annual visit to Switzerland, collecting, noting and photographing. He was an expert photographer and his catalogue is profusely illustrated by photographs of his own taking. Niany of these were used to illustrate "Die Mineralien der Schweizeralpen" by Niggli, Koenigsberger and Parker, with whom Ashcroft collaborated. Others appear as plates in Arthur Holmes's "Principles of Physical Geology".

It was an education to accompany Asheroft on one of these visits to the Alps and to see him at work. $\mathrm{He}$ had gained the affection of mineralogists and mineral collectors all over Switzerland, and if they were sorry to see their best specimens being taken to London year after year, they forgave him for the big kind-hearted enthusiast that he was. His collecting trips were usually followed by a holiday with his family. He had married in 1904 Constance Muriel, daughter of J. C. Im Thurn, and had two sons and two daughters. He was devoted to his family and very proud of his grandsons, and they were all de. voted to him.

$\mathrm{He}$ had many friends among mineralogists at home and abroad. He was a member of the Swiss Mineralogical Society and of the Museums Associa. tion as well as of the other societies mentioned, and he was a charter member of the Mineralogical Society of America.

W. Campbell Smith

\section{Mr. Edward Heawood}

816

Mr. Edward Heawood, emeritus librarian of the Royal Geographichociety, died on April 30, in his eighty-fifth

Heaw pil 1 as attracted to geography through an early intrest in natural history, and the great narr tiges of exploration. After taking his degree in classid at Cambridge, he received instruction in surveying and other field studies at the Royal Geographical Society, and spent two years in India working on a settlement scheme among the Santals in the Bengal Duars. On his return, he joined the staff of the Society, assisting with the newly estab. lished Geographical Journal and in the library. On the retirement of Dr. H. R. Mill in 1901, he succeeded him as librarian, an appointment which he held until 1934. During these years the Society's Library expanded considerably under his guidance, particu. larly in its collections of foreign geographical periodicals and of early geographical texts and atlases. His extensive knowledge of the literature of geography, aided by an exceptional memory, was readily placed at the disposal of students.

His special interest was at first in African geo. graphy and in the history of exploration generally. His "History of Geographical Discovery in the 17th and 18th Centuries", published in 1912, is a careful and comprehensive study which remains the best general guide to that period. This line of study led naturally to that of the cartographic sources, to which his attention was increasingly given, until he had established a widely recognized reputation as an authority. Most of his work is to be found in the Geographical Journal, in numerous notes and reviews as well as in longer papers, but two important memoirs appeared as separate publications of the Royal Geographical Society : "The Viap of the World on Niercator's Projection by Jodocus Hondius, 1608" (1927) and "English County Maps in the Collection of the R.G.S." (1932). A further development of this work, which was perhaps his most individual contribution, was his extensive study of water-marks used by paper-makers, which threw much light on the sources and distribution of paper, in addition to its use in dating maps and other documents. He concentrated upon marks on paper used in England, filling in the gap left by Briquet and other Continental writers. His first article, in the Geographical Journal of May 1924, was followed by others in The Library of 1930,1931 and 1948. On the day of his death he had been at work on an index to a selection of his tracings of marks, which is to be published in Holland.

Heawood received the Research Viedal of the Royal Scottish Geographical Society in 1933, and in the following year the Victoria Viedal of the Royal Geographical Society. For many years he was treasurer of the Hakluyt Society, and had been recorder of Section E (Geography) of the British Association.
G. R. Crone 